\title{
Contemporary Development Financial Institutions in Europe
}

\author{
Marco Frigerio, Stefano Clò, Daniela Vandone \\ University of Milan, \\ Department of Economics, Management and Quantitative Methods
}

\section{Introduction}

In the last few years, the slowing trend of privatization and the persistence and growth of state-owned or state-invested enterprises, an emerging wave of protectionism, increasing state intervention in the economy, particularly in reaction to the financial crisis, brought many scholars and public opinion leaders to speak about "the rise of state capitalism" (The Economist special report, January 21st, 2012). This is a new form of state capitalism: it has been spreading across both developed western countries and emerging countries, such as China, India, Russia or Brazil. It is not anymore a domestic phenomenon and it is taking place at an international level in a globalized economy. While Musacchio and Lazzarini (2012) define this new form of hybrid State capitalism as "the widespread influence of the government in the economy, either by owning majority or minority equity positions in companies or through the provision of subsidized credit and/or other privileges to private companies", Bremmer (2009) identifies four primary actors which characterize contemporary State Capitalism: national oil corporations, state-owned enterprises, sovereign wealth funds and privately owned national champions. Quite surprisingly, Development Financial Institutions (DFIs) have not been properly taken into consideration within the State capitalism framework.

DFIs - also referred to as State Investment Banks, Development Banks, Promotional Banks - are public sector or government-invested legal entities with an explicit policy mandate to promote the socio-economic goals in a region, sector or specific market segment. They are playing a relevant role in the economy, since they provide financial services to strategic sectors, sustain growth during period of recession, invest in physical and technological infrastructures. Besides, more recently, they are increasingly addressing their activity to yield social payoffs and positive externalities for society as a whole, such as stimulating technology innovation and channelling funds to long-term global societal challenges such as climate change, renewable and environmental-friendly energy, food security (World Bank 2013, EIB 2014). Indeed, as stated in their statutes, the DFI purpose includes, among other, to promote environmentally and socially sound and sustainable development (European Bank for Reconstruction and Development), to provide added value in energy, transport and environmental improvements (Nordic Investment Bank), favour of social cohesion thorugh the strenghtening of social integration, management of the environment, supporting public infrastructure with a social vocation (Council of Europe Development Bank), to contribute towards the integration, balanced development and economic and social cohesion of the EU Member States (European Investment Bank).

DFIs are also growing in size: data from Orbis Bank Focus and Orbis (Bureau Van Djik) report that the total assets managed by European DFIs in 2015 were 3,007 billion euros, three times higher than the total assets in 2005 (966 billion euros). ${ }^{1}$ In the same

\footnotetext{
${ }^{1}$ See Section 3 for the mapping of European DFIs within the BvD databases.
} 
period, their aggregate loan portfolio was more than 1,300 billion euros, more than two times higher than in 2008 (531 billion euros), after DFIs started playing a relevant counterciclycal role in the economy, that was seriously hit by the financial crisis and the following economic recession. Indeed, as a consequence of the Great Recession, DFIs increased the supply of credit or equity investment to the private sector while private banks experienced temporary difficulties (World Bank 2011, 2013; OECD, 2012).

In spite of their recent increasing activity and role, and apart some notable exeptions (Yeyati et al. 2007; Lazzarini et al. 2015), DFIs have not deserved a proper attention in the academic literature and they remain a quite under-analysed phenomenon. We believe that DFIs play a non-negligible role in the economy, and notably within the State capitalism framework, and we would like to fill this gap with a detailed analysis of firm-level characteristics and activities of contemporary DFIs in Europe.

This chapter is structured into three main sections. Section 2 introduces the phenomenon of development banks, explains the traditional theoretical framework where the existence of DFIs is discussed and why they represent a rising and important component of State Capitalism. Section 3 describes the characteristics of contemporary DFIs in Europe and discuss their growing role in funding innovation and supporting a response to global and new societal challenges. Section 4 presents the empirical analysis, which aims at discussing the role of DFIs as vehicles for state intervention in several sectors, with a specific focus on their strategic support to innovation. Section 5 concludes.

\section{Literature Review}

The main economic rationale for the existence of DFIs is the Market Failure Theory, back to the middle of last century. In his seminal paper, Bator (1958) defines market failures as "the failure of a more or less idealized system of price-market institutions to sustain 'desirable' activities or to stop 'undesirable' activities'. In the economic literature, "market failure" is used to refer to situations where markets are inefficient and supply less than a Pareto-optimum level of services and goods (Arrow-Debreu). Such inefficiencies may come from several sources, like imperfect or incomplete information (Akerlof, 1970), existence of externalities (Coase, 1960; Greenwald and Stiglitz, 1986), managers" desire for a "quiet life" (Hicks, 1935; Leibenstein, 1966).

Within this framework, the underlying idea is that institutions with a public policy mandate are better placed than private operators to overcome market failures - such as asymmetry of information, externalities, latent capabilities, coordination problems, strategic trade - and ensuring the functioning of existing markets (Diamond, 1957; Armendariz de Aghion, 1999).

Indeed, DFIs typically fund projects with high risk, that private banks may not finance if there are difficulties in evaluating the business, the innovation process, and therefore the expected returns and their distribution over time, or if there is a lack of guarantees and collaterals, or a lack of a track-record of profitable investments, which is typically the case of high-tech or new industries, start-up and R\&D investments. DFIs may step in providing direct or indirect loans, credit guarantees and equity tools such as venture capital, private equity, seed capital financing or mezzanine financing to enable firms to access the capital necessary for growth (Musacchio et al. 2017; Mazzucato and Penna 2016; Bleda and Del Rio 2013).

DFIs also provide long-term "patient" capital to promote strategic investments for economic development (e.g. infrastructure projects, export, housing, etc.) or for socially challenging projects (e.g. climate finance, renewable and environmental-friendly energy, 
food security initiatives). Their financial support aims at overcoming funding gaps stemming from a private sector being reluctant to provide funding to socially valuable projetcs which may result unprofitable, at least in the short run, due to the impossibility to monetize positive externalities, (Foray et al 2012; Eslava and Freixas 2016; De Olloqui 2013; Yeyati et al. 2007).

Besides, DFIs play a countercyclical role in time of crises, by sustaining growth and employment during periods of recession, when banks typically disintermediate their credit activity because of deteriorating asset quality, capital shortages, deleveraging and higher risk aversion. In recent years, this countercyclical role has come to light in response to the Global Financial Crisis (Gutierrez et al 2011; Yeyati et al 2007; LunaMartinez and Vicente 2012).

More recently a new body of literature is highlighting that the relevance of DFIs goes beyond ensuring the functioning of existing markets by setting market failures, since contemporary DFIs are also stimulating innovation and supporting a response to new global challenges which are broader in nature and require actions from both private and government players (Bleda and Rio 2013; Foray et al. 2012; Mazzucato and Penna 2016; Eslava and Freixas 2016; European Commission 2014). The need for structural answers to new challenges is stressed in the light of a rising financialization of both financial and non-financial companies. Indeed, financial deregulation, liberalization and globalization has increased banks' focus on short-term profit maximization by means of adopting speculative investment policies in financial instruments and, therefore, has reduced banks' traditional role of transforming savings into productive investments and reduced the willingness to supply patient capital (Sorsa and Van Der Zwan 2016; Hardie and Howarth 2013). Entrepreneurial activity has become more financialised as well, with an increasing share of highly liquid financial assets in firms' portfolios, increased leverage and reduction of outstanding equity aimed at increasing shareholder value, at the expenses of productive investments in their core business (Orhangazi 2008).

While the theoretical literature discussing the role and the existence of development banks is substantial, empirical studies on DFIs' firm-level characteristics and on the impact of their activity mainly focus on a particular financial institution or country.

As far as Europe, Clifton et al. (2014) analyzes the role of the European Investment Bank (EIB) in financing utilities over the long-term. The dataset comprises micro-data on projects cofinanced by the EIB in the utility sector, from 1958 to 2004 and the analysis highlight three phases. The first, from 1958 to 1972, was characterized by financing development of the poorest regions of European Members, and lending to sustain transport was by far the dominant sector. This phase was interrupted by the 1973 oil crises, and the subsequent need to change lending priorities towards the objective of reducing energy dependency and, in turn, the balance of payments. Besides energy, and in particular nuclear power programs, telecommunication as well as water and waste were other relevant sectors to receive finance during this phases that ends up in the middle of 1980s. The last phase is framed in a context of deregulation and privatization of both the financial and the utilities sectors, and a deeper European integration. During this period, aimed at bolstering the Single Market project, key sectors of EIB's funding support were the Trans European Network programs, particularly road and rail trasport, that is projects whose positive externalities cannot belong, and therefore captured, by one single Member State.

Besides, Clifton, Diaz-Fuente and Gomez (2018) analyzes EIB lending to its Member States and focuses on the period from 1958 up to 1995, which represents a turning point 
for the EU in terms of a new political and economic environment (e.g. end of the Cold War, the reunification of Germany, the signing of the Maastricht Treaty) that changed the original economic conditions that gave birth to the EIB. The authors find that lending from EIB was consistent with the objective to the purpose the EIB was created, that is promoting regional economic integration and development and not just alleviating capital constraints and promoting development.

Robinson 2009 investigate the role of the EIB activity in the development of the EU policy process by focusing on the catalytic effect of EIB' $s$ lending and the contributions to EU expenditure due to its leveraging effect. It also analyzes EIB' $\mathrm{s}$ capacity to mobilize sub-national actors, strengthen the role of the Commission and weaken that of the Member States. Similarly, Mertens and Thienmann 2019 frame the recent institutional co-operation between the EU, the EIB and national promotional banks in the context of European integration. Indeed, the European Fund for Strategic Investments and the European Investment Advisory Hub, which are the two strategic pillars of the 2014 socalled "Junker Plan" , are co-sponsored and managed by the European Investment Bank (EIB), and a relevant number of national promotional banks are cooperating at regional level. Finally, Tuijnman 2009 analyzes the educational lending portfolio of the EIB

Outside Europe, the most relevant paper empirically assessing the activity of DFIs is Lazzarini et al. (2015) who analize the impact of long-term credit provided by the Brazilian National Bank for Economic and Social Development (BNDES) on the performance and investment activity of firms receiving its funds. The aim is to test which of the two existing views - industrial versus political - on the role of public banks is prevailing. In fact, according to the industrial policy view, DFIs should improve firms' investment and performance since DFIs' funds allow firms to undertake capital expenditures to capture economies of scale or acquire new technology. Conversely, according to the political view, since allocation by DFIs may be driven by reasons other than efficiency, loans are simply a transfer from the bank to the economy without necessarily having any positive effect on business-level activity. Panel data on loans and equity are collected from the balance sheet and the ownership composition of 286 companies listed in the Sao Paulo Stock Exchange between 2002 ans 2009, and individual firm's donors to politicians are matched with election results to capture the extent of a firm's political activity. Empirical results highlight that although political connection matters, funds are not channeled to firms with bad performance. BNDES loans and equity allocations do not appear to have a consistent effect on the performance and investment decisions of firms probably because these firms could fund their projects with other sources of capital.

Few other qualitative and quantitative information on DFIs can be found into reports from the World Bank, overall highlighting the weeknesses of existing development banks specifically related to their governance and efficiency, which in turn may impair thire impact on growth. For example, Luna-Martinez and Vicente (2012) report the results of a survey on a sample of 90 development banks across 61 countries aimed at analyzing their activity and their financial characteristics and find that on the overall development banks continue to play an active role in the economy by providing credit to select sectors and fostering new investments in priority activities such as clean energy. The authors, however, also find that there is a certain level of heterogeneity among institutions so that some of them are less performant and efficient and an effort need to be done by policy makers in order to to continue modernizing their DFIs and giving them tools to become more effective and successful in fulfilling their policy mandates. Similarly, Gutierrez, 
Rudolph, Home and Beneit (2011) highlight best practices in development banking for policy makers to build strong financial institutions to address current and future needs in their respective countries to ensure that these banks effectively serve a clear purpose, are run efficiently and do not create market distortions. Francisco, Mascarò, Mendoza and Yaron (2008) develop and test a methodology for evaluating the performance of development finance institutions which applies assessment criteria taking into account both the social objective that the development finance institution addresses and the subsidies it received in order to achieve such an objective in order to assess the effectiveness associated with meeting the social objective ${ }^{2}$.

In the next Sections, we aim to contribute to the existing empirical literature with an analysis on the main financial characteristics of contemporary DFIs, their main activities and the role they are currently playing in their reference areas. We focus on DFIs in Europe in order to analyze their specificities within a homogeneous institutional and economic environment.

\section{Contemporary DFIs in Europe: characteristics and main activities 3.1 Mandates and business models}

DFIs have the broad mission to promote development. In performing their activity, they may invest inside the establishing country (or member countries if supranational), as well as they may promote development in developing and emerging countries, especially where socio-economical relationships were already in place. The target sectors typically vary depending on whether the mandate of the DFIs is narrow or formulates without reference to any particular activity. Generally, multilateral and large size DFIs have broad and more flexible mandates.

Besides, DFIs may provide finance to financial intermediaries that in turn on-lend (socalled second-tier lending) to end-customers, or they may support directly end-customers, such as individuals and households, start-ups, micro, small and medium enterprises, large private corporations, other financial institutions, other state-owned enterprises (so-called first-tier lending). DFIs pursue their mandate using several financial instruments, such as loans, guarantees, mezzanine finance, risk-sharing instruments, equity. They also offer non-financial services such as technical and administrative assistance, advisory services, training programs. On the liability side, DFIs typically fund their activity issuing bonds, receiving budget transfer from the government, European programmes, other financial institutions or DFIs. The vast majority of European DFIs are not allowed to directly take retail deposits. This is strongly reflected in the financial characteristics of DFIs with respect to private and state-owned commercial banks, as discussed in Section 3.3.

\subsection{Ownership and country distribution of DFIs in Europe}

So far, European DFIs have not been collected in a comprehensive dataset. Therefore, the first step of this research has been to map and indentify these financial intermediaries.

\footnotetext{
2 There is also a body of literature that specifically investigates the role of politics on the behavior of government-owned banks during election years, with the aim to assess whether their activity is possibly influenced by political considerations (Dinc, 2005; Micco et al., 2007; Sapienza, 2004). However, this existing literature has so far focused only on commercial state-owned banks or has considered state-owned banks as if they belonged to the same type. Conversely, as highlighted in Section 3.3, there are clear differences between development and state-owned banks, in terms of mission, business models, type of activity, and targeted market segments (Bacchiocchi et al., 2017; Luna-Martinez and Vicente, 2012; Lazzarini et al., 2015; Schmit, Denuit, Gheeraert, \& Warny, 2011; Yeyati et al., 2004).
} 
We select a list of European DFIs by extrapolating information from the Orbis Bank Focus and Orbis firm-level databases, both produced by Bureau Van Dijk (BvD). We first identifyied and selected most of the European DFIs of our final sample by directly referring to the firms' description available within the BvD data sources. We then refined the initial selection of European DFIs through manual inspection, online research and a general review of annual reports and public available information.

The final list includes 132 entities, which to the best of our knowledge represent the population of DFIs in Europe.

Depending on the number of governments controlling them, DFIs can be distinguished into supranational and national financial institution. Eight of the 132 DFIs have been identified as supranational (also called multinational): the European Investment Bank (EIB) with its subsidiary, the Europeain Investment Fund (EIF), the European Bank for Reconstruction and Development (EBRD), the Black Sea Trade and Development Bank (BSTDB), the Nordic Investment Bank (NIB), the Council of Europe Development Bank (CEB), the International Bank for Economic Co-operation (IBEC) and the European Company for the Financing of Railroad Rolling Stock (EUROFIMA). The remaining 124 DFIs are ultimately controlled by national (or even regional or local) governments. Among them, the biggest in size in terms of total assets are the KfW (Germany), the Cassa Depositi e Prestiti (Italy), the Caisse des Depot e de Consignations (France), NRW.BANK (North Rhine-Westphalia, Germany), Rentenbank (Germany's Development Agency for Agribusiness), SFIL (French development bank created in 2013 with the aim of guaranteeing stability in local public sector financing), NWB Bank (the Netherlands), the Instituto de Credito Oficial (Spain).

Table 3.1 provides information on the distribution of DFIs by country in terms of number and total assets.

Table 3.1. Distribution of DFIs by country in terms of number and total assets

\begin{tabular}{|c|c|c|c|c|}
\hline \multirow{2}{*}{ Country } & \multicolumn{2}{|c|}{ By Tot.Ass. (2013-2015) } & \multicolumn{2}{|c|}{ By Number } \\
\hline & EUR billion & $\%$ & Obs. & $\%$ \\
\hline Supranational & 734.4 & 24.8 & 8 & 6.1 \\
\hline Germany & 925.8 & 31.3 & 18 & 13.6 \\
\hline Italy & 406.1 & 13.7 & 10 & 7.6 \\
\hline France & 329.9 & 11.1 & 10 & 7.6 \\
\hline Netherland & 95.5 & 3.2 & 3 & 2.3 \\
\hline Russia & 91.2 & 3.1 & 5 & 3.8 \\
\hline Spain & 89.2 & 3.0 & 7 & 5.3 \\
\hline Sweden & 72.8 & 2.5 & 6 & 4.5 \\
\hline Norway & 58.0 & 2.0 & 4 & 3.0 \\
\hline Finland & 37.2 & 1.3 & 6 & 4.5 \\
\hline Denmark & 27.5 & 0.9 & 2 & 1.5 \\
\hline Turkey & 24.8 & 0.8 & 6 & 4.5 \\
\hline Poland & 15.2 & 0.5 & 2 & 1.5 \\
\hline Belgium & 7.4 & 0.3 & 10 & 7.6 \\
\hline
\end{tabular}




\begin{tabular}{lcc|cc} 
United Kingdom & 7.3 & 0.2 & 8 & 6.1 \\
Other & 37.6 & 1.3 & 27 & 20.5 \\
\hline Total & $2,959.8$ & 100.00 & 132 & 100.00 \\
\hline
\end{tabular}

Source: Our elaborations on financial items obtained from Orbis Bank Focus and Orbis (databases from Bureau Van Dijk)

In terms of sample size, the countries with the highest number of DFIs are Germany, Italy, France and Belgium. The first three are also the ones with the greatest weight in terms of total assets (according to median values by bank in the period 2013-2015): Germany (31.3\%), Italy (13.7\%), France (11.1\%), while supranational DFIs account for a quarter of DFIs' total assets. This heterogenous incidence is affected by the different average size of DFIs within each country. For example, in Italy there is a large national promotional bank - i.e. Cassa Depositi e Prestiti (whose average total assets amount to approximately Euro 380 billion within the period 2013-2015) - and a plurality of very smaller regional DFIs (the largest of which is the Banca del Mezzogiorno - Mediocredito Centrale, with about Euro 2.1 billion of total assets within the same period). A similar situation can be observed in France, where large differences in size exist between Caisse des Dépôts et Consignations (about Euro 149.5 billion of total assets ${ }^{3}$ ), the Caisse de Garantie du Logement Locatif Social (Euro 0.840 billion) and other DFIs that operate on a national basis but on a much lower scale. The case is different in Germany, where KfW (about Euro 485.6 billion) is accompanied by the presence of some landesbanken and sparkassen of considerable size (for example, NRW.Bank with about Euro 143.5 billion of total assets).

Table 3.2 highlights considerable heterogeneity in the size of DFIs, both in terms of their total assets and employees, as revealed by the high ranges, i.e. the differences between the maximum and minimum observed values. Very higher values of the mean with respect to the median indicate that the distribution of national DFIs is skewed to the right, while the opposite is true for supranational banks. In terms of total assets, the largest DFI is the EIB, while the largest national DFI is the German KfW. By contrast, the largest DFIs in terms of number of employees are the Russian Agricultural Bank and the Italian Cassa Depositi e Prestiti (CDP).

Table 3.2. Total assets and employees across European DFIs (2013-2015 averages)

\begin{tabular}{lrrrrr}
\hline Year: 2013-2015 & Mean & St.Dev. & Min & Median & Max \\
\hline Supranational DFIs: & & & & & \\
Tot. Assets $(€$ bln) & 90.1 & 204.9 & 0.0 & 23.4 & 595.4 \\
Employees & 856.3 & 1050.6 & 104.7 & 241.3 & $2,517.3$ \\
\hline National DFIs: & & & & & \\
Tot. Assets $(€$ bln) & 19.9 & 62.6 & 0.0 & 1.9 & 485.6 \\
Employees & $1,446.5$ & $5,476.7$ & 4.0 & 155.7 & $34,703.7$ \\
\hline Source: Our elaborations on financial items obtained from Orbis Bank Focus and Orbis (databases from \\
Bureau Van Dijk). Note: Statistics in the table refer to our sample of 132 DFIs. For each DFI we take
\end{tabular}

\footnotetext{
${ }^{3}$ The CDC's total assets would increase to about Euro 400 billion in the same period if we also added the Saving Fund Division activities (management of savings and social housing financing on behalf of the French State) to the official consolidated activities.
} 
average values within the time interval 2013-2015.

\subsection{The financial characteristics of DFIs: a benchmark analysis}

Firm-level balance-sheet information on DFIs describe the specificities of their activity, both on the asset and the liability side, which is in turn reflected in the relative weight of profit and losses items.

For a more meaningful analysis of the financial characteristics of DFIs, commercial banks are used as benchmarks. Among commercial banks, we also distinguish between state-owned banks (SOB) and private-owned banks (POB). In spite of being ultimately controlled by governments as well, SOBs differ from DFIs because they typically: i) do not have an explicit public policy mandate, ii) operate like private banks offering a wide variety of banking and financial services targeted to retail as well as corporate customers and covering deposits and accounts, credit cards, loans, stock market services, insurance, asset management, etc. (Lazzarini et al., 2015; Luna-Martinez and Vicente, 2012).

Our sample refers to the entire European continent and includes a total of 5,576 financial institutions with available financial information within the reference period 2000-2015. In addition to the 132 DFIs identified above, it also includes 5.122 POBs and 322 SOBs, of which 112 have been nationalized during the reference period, especially as a consequence of the financial crisis. We considered to be state-owned any bank of which the ultimate owner, defined as the independent shareholder with the highest direct or total percentage of ownership, is a central or local public entity, including public authorities, governments, municipalities and local entities. Furthermore, we considered the independent shareholder to be an ultimate owner (UO) of a bank if it holds more than $25 \%$ of the shares, usually regarded as granting control or at least a large influence in decision-making (see, for example, Christiansen and Kim, 2014; Micco et al., 2007).

Overall, $2.4 \%$ of our sample is composed by DFIs, $5.8 \%$ by SOBs. In terms of total assets (2013-2015 average), the weight of DFIs and state-owned banks increases to 5.5\% and $14.8 \%$ respectively, due to their higher average size compared to private banks.

Descriptive statistics are reported for the most relevant ratios (Table 3.3). For each ratio, and within each year, a winsorizing procedure has been applied to replace values higher than the 99th percentile and lower than the first percentile respectively with the 99th percentile and the first percentile, in order to avoid any strong influence of extreme values on statistics.

Table 3.3 Descriptive statistics across clusters (2000-2015)

\begin{tabular}{lccc|ccc}
\hline & \multicolumn{3}{c}{ Mean } & \multicolumn{3}{c}{ Median } \\
\hline ROE & POBs & SOBs & DFIs & POBs & SOBs & DFIs \\
ROA & 5.3 & 2.8 & 5.0 & 4.5 & 4.7 & 3.6 \\
Equity/TotalAssets & 0.6 & 0.3 & 1.1 & 0.4 & 0.5 & 0.5 \\
Cost-to-income & 12.3 & 14.8 & 35.2 & 8.8 & 10.8 & 23.5 \\
& 70.7 & 71.0 & 57.4 & 70.4 & 66.1 & 50.2 \\
Net Interest Margin & & & & & & \\
Interest income/avg. interest earning assets & 5.3 & 3.3 & 2.5 & 2.6 & 2.6 & 1.7 \\
Interest expense/avg interest bearing liabilities & 2.6 & 3.2 & 3.7 & 2.1 & 2.5 & 3.4 \\
& & & & & & \\
Impaired loans / Gross loans & 5.3 & 12.6 & 8.0 & 3.1 & 5.6 & 5.2
\end{tabular}




\begin{tabular}{lccc|ccc} 
Loan loss provisions / Net interest revenues & 16.4 & 30.4 & 21.6 & 12.7 & 17.5 & 14.2 \\
Customer deposits / total funding & 69.9 & 56.3 & 26.0 & 77.6 & 64.4 & 11.0 \\
Net Loans / Retail funding & 276.9 & 402.7 & $1,852.4$ & 93.5 & 118.9 & 819.5 \\
& & & & & & 1.4 \\
Total Assets, Euro billions & 7.9 & 24.6 & 20.3 & 0.3 & 1.2 & 1.4 \\
Number of employees & $1,221.5$ & $3,791.0$ & $1,137.2$ & 118.0 & 384.0 & 128.0 \\
\hline
\end{tabular}

Source: Our elaborations on Orbis Bank Focus and Orbis (BvD)

Note: Values indicate percentages unless otherwise specified.

Firm-level data highlight that DFIs have a higher performance, both in terms of profitability measured by the Return-On-Asset ratio and efficiency, proxied by the costto-income ratio. Their core activity is lending, and their median size is far bigger than the benchmarks. Differences can be ascribed, among others, to the type of activity performed and the business model. In particular, the cost to income ratio, obtained as the ratio between overheads (operating costs) and income before provisions (given by the sum of net interest revenues and other operating income), reveal a higher efficiency level for the DFIs, likely due to the low incidence of fixed costs related to the branch network, notwithstanding a similar average number of employees.

On average, they are significantly larger in size than private banks in terms of total assets, but not in terms of number of employees. Besides, DFIs differentiate from public and private commercial banks for a significantly lower share of retail deposits (retail funding).

The average and median ROA (return on assets) of the DFIs is higher than that of the SOBs and POBs, while in terms of ROE (return on equity) private banks tend to perform better than the DFIs. This is largely attributable to the higher leverage of private banks, as evidenced by the significantly lower equity-to-assets ratio.

As for the net interest margin, we need to distinguish between its two components, i.e. revenues generated by interest-bearing assets and the cost of servicing (interest-burdened) liabilities. The lower net interest margin of DFIs seems to be due to the higher value of the latter. Indeed, our sample reveal that DFIs' interest income as percentage of average interest-earning assets is in line with that of POBs, while interest expense on average interest-bearing liabilities is higher. This is not surprising if one considers that a large part of the DFIs' funding is raised from the capital market and is long-term, and therefore more expensive. Evidence from some case studies seems to confirm that the higher interest expense as a percentage of interest-bearing liabilities can be attributed not so much to a higher cost of funding but rather to a different composition of the DFIs' funding itself. Indeed, DFIs tend to recur to higher shares of long-term funding than commercial banks, that instead have greater access to low-cost funds through customer deposits (retail funding). ${ }^{4}$

\footnotetext{
${ }^{4}$ As an example, we can compare the median observations of the DFI cluster and the POB cluster with respect to the interest expense as percentage of interest-bearing liabilities. Among the DFIs, the median subject is LfA Förderbank Bayern, a specialist promotional bank of the Free State of Bavaria. In 2012-15, LfA Förderbank Bayern has a median annual total interest paid higher than $€ 450 \mathrm{mln}$ and interest-bearing liabilities slightly higher than $€ 20,000$ million. Long-term borrowings and debt securities weigh more than $30 \%$ on interest-bearing liabilities. Among the POBs, the median subject is Raiffeisenbank eG Neustadt, a cooperative bank that is based in Germany as well. In 2012-15, Raiffeisenbank eG Neustadt has a median annual total interest paid of approximately $€ 3.2 \mathrm{mln}$ and interest-bearing liabilities slightly higher than $€$
} 
Finally, the higher percentages of impaired loans are in line with the mission of the DFIs and the role they play in setting market failures, as previously discussed.

\subsection{The activities of DFIs and the role in fostering innovation: selected examples}

Figure 1 highlights the evolution of the incidence of development financial institutions and state-owned banks on total assets of the whole European banking system. The chart shows that the weight of state-owned banks increased by about 5 percentage points as a consequence of the crisis, due to nationalizations and deleveraging among private-owned banks. Nationalizations are concentrated in two distinct phases: 2008-2009 with the global financial crisis and 2012-2014 with the sovereign debt crisis. The weight on total assets has progressively grown for development banks as well, suggesting that they played a notable countercyclical role in response to financial crisis. Indeed, since the development banks belong permanently to the same cluster (as no significant changes affect their public ownership and their mandate during the reporting period), their rising weight within the banking system is just due to a greater resilience of their activity compared to private banks in the crisis years.

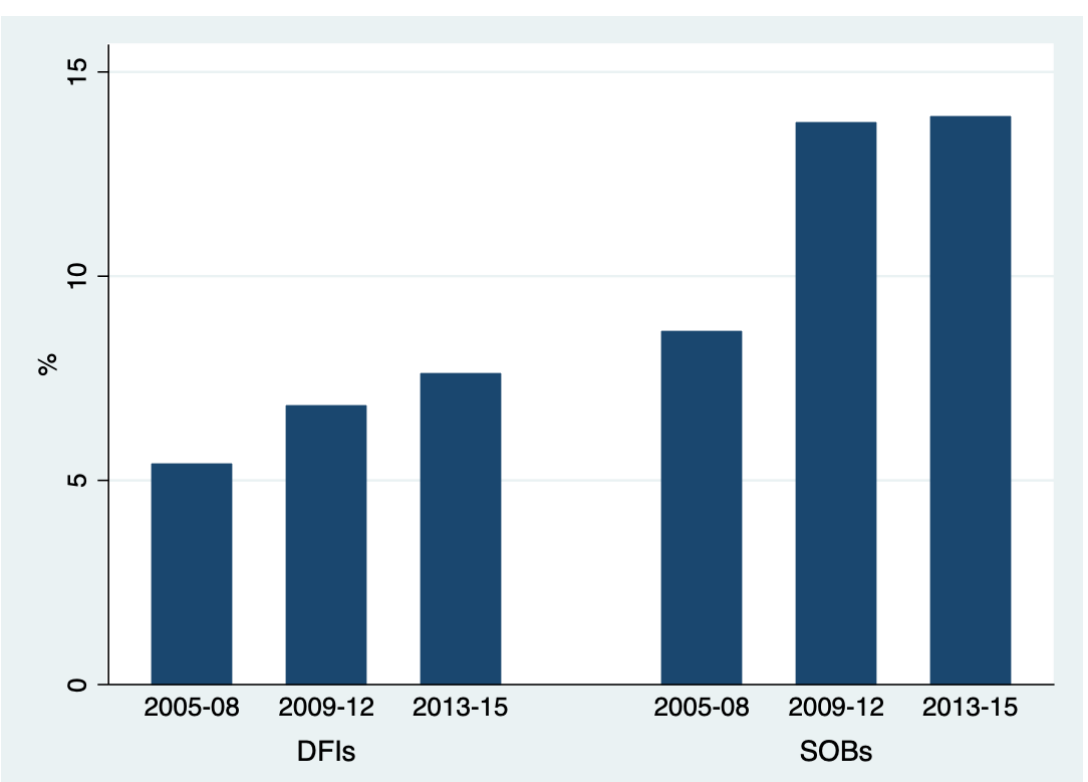

Figure 1 - Incidence of development banks (DFIs) and commercial state-owned banks (SOBs) on total assets of the banking system

In recent years, DFIs' intervention in the real economy changed not only quantitatively, but also qualitatively. While historically DFIs have been an instrument used by governments to promote economic development by fostering processes of industrialization, reconstruction, creation of infrastructures, nowadays their main emphasis is on supporting SMEs, digital infrastructure, social housing, and education.

Besides, a rising number of DFIs have started to play a key role in technology promotion and innovation and in supporting structural changes in economies like

280 million. The lower ratio is justified by the fact that in the latter case long-term borrowings and debt securities are almost zero, since almost all of the financing is based on customer deposits. 
renewable energy, resource efficiency, food security, ageing, population growth, and climate change. At a worldwide level, the Global Landscape of Climate Finance (2015) reports that climate finance represents a rising share of DFIs' business volume, on average almost $30 \%$ with peaks up to $50 \%$. In 2014, DFIs' commitments were almost $33 \%$ of total climate finance flows.

Box 3.1 describes the investment portfolio of the main European DFIs to highlight their activities, especially in fostering innovation and channelling funds to long-term societal challenges.

\section{Box 3.1. Investment portfolio of the main European DFIs}

\section{The European Investment Bank (EIB)}

Together with the European Commission, the EIB launched in 2015 the European Fund for Strategic Investments (EFSI) with the aim to mobilize private financing for strategic investments and addressing the market failure in risk-taking by supporting investment and increasing access to finance for SME's and mid-cap comapanies. By June 2016 the EFSI approved 262 operations for a financing amount of 17.45 billion Euro, which represents a total investment mobilized of 104.75 billion Euro.

Besides, in 2014, together with the European Comission, the EIB launched the InnovFin - EU Finance for Innovators, aimed at financing research and innovation by companies, small to large, young to well-established, and the promoters of research. The program also includes thematic products addressing the specific financing needs of certain innovative sectors which traditionally find it difficult to access finance. For example, the InnovFin Energy Demo Project targets innovative first-of-a-kind commercial-scale demonstration projects to help companies to bridge the gap from demonstration to commercialization. Similarly, the InnovFin Infectious Diseases Finance Facility provides financial products for R\&D-oriented companies to develop new innovative vaccines, drugs, medical and diagnostic devices or novel research infrastructures. Since 2014, the InnovFin program has financed 87 projests mainly in ICT, Telecom \& Media (17\%), Life Science, Medical Technology, Pharma \% Healt Care (13\%), Energy (13\%), Metallurgy, Manufacturing and Process Industries (13\%). Among institutions and companies supported there are: CERN $(\mathrm{CH})$, Novabase (PT), Welltec (DN), AW-Energy (FL).

\section{The European Bank for Recostruction and Development (EBRD)}

In 2015, the EBDR invested a total amount of 9.4 billions Euro. Financial institutions received $32 \%$ of EBDR's total investment for in-turn investments to MSMEs in sustainable energy and resource projects. Examples: loans to Akbank, Garanti and Yapı Kredi (Turkey) to fund midsized renewable energy projects undertaken by private companies; loans to BZ WBK Leasing and Bank Millennium (Poland) to provide leasing finance for energy efficiency investments; loan to Bank Eskhata (Tajikistan) to finance mechanism aimed at building resilience to the effects of climate change.

Energy is the second largest EBDR's lending segment (27\%), aimed at supporting projects that promote the sustainable use of resources and protection of natural assets, such as the prevention of pollution of remedying of damage to ecosystems. Examples: investments in the power sector for renewable or low-carbon energy generated by wind, solar or hydropower, biogas, biomass or geothermal technology; funding for urban regeneration, earthquake-proof and energyefficient residential and student housing.

\section{The Nordic Investment Bank (NIB)}

The NIB invested a total amount of 3,373 million Euro in 2016.

Energy is the largest segment of NIB's lending activity (35\%). Projects financed includes wastewater treatment, investments in electricity transmission, distribution networks and smart metering systems, hydropower, biomass and industrial energy plants. Examples: funding to the 
Finnish Helen Oy for the construction of a wood pellet heating plant and an underground cooling center in order to increase the proportion of renewable fuels in the energy production. Infrastructure and Transportation is the second sector (27\%). This lending area covers urban transport projects and airport enlargements, modernisation and enlargment of educational infrastructure, water supply facilities. Examples: lending to the Aalto University Foundation for the construction of new premises that will allow for higher energy efficiency and more flexible teaching space solutions.

Besides, since 2011, the NIB has issued a total of EUR 2.1 billion green bonds to finance projects with a positive impact on the environment (e.g. 20-year loan to construct a water pipeline for drinking water from Lake Mälaren in Sweden; a 7-year loan to finance R\&D in plant breeding and grass biotechnology in Denmark; a 15-year loan to finance the construction of a high-performance hydroelectric station inside mountains; a 20-year loan to finance the construction costs of a new waste-to-energy plant in the Helsinki Metropolitan Area to convert garbage into energy and heat).

\section{The Kreditanstalt für Wiederaufbau (KfW)}

The KfW new commitments in 2015 were equal to 79.3 billions Euro.

KfW supports innovative start-up entrepreneurs, the self-employed and SMEs with a broad spectrum of financing and advisory services with the aim to create a funding environment for innovators. Among the financial instruments used by KfW to support SMEs, the most relevant are the "ERP innovation programme", that provides long-term funding for the development of new products, product processes and services, and the "EPR Start - up Fund", which is specifically involved in the young companies' foundation phase. KfW also indirectly invest in young companies through the "ERP Venture Capital Fund Investments", that is provision of funds to venture capital in order to leverage private capital for innovative start-up.

The KfW places also emphasis on financing investments in climate and environmental protection, with programmes such the "KfW Energy Efficiency Programme", that offers SMEs favourable financing for energy efficiency measures, or the "Energy-efficient Construction and Refurbishment" which is aimed at financing investments in new construction or rehabilitation of energy-efficient commercial buildings, or the "KfW Environmental Protection Programme" that provides low-interest, medium to long-term financing for environmental protection and investment measures aimed at improving resource efficiency as well as waste avoidance and recycling.

\section{The Cassa Depositi e Prestiti (CDP)}

The CDP promotes the development of the Italian economic-industrial system, financing activities to support national growth and investing in competitiveness. In particular, the CDP supports general government investments and international cooperation in the construction of infrastructures, supports the export sector and enhances publicly owned real estate, social housing and smart housing, and drives new initiatives to support Italian companies throughout their life-cycle - starting from the planning stage. Funding is mainly represented by venture capital financing, such as VC Fund of Funds, Late Stage VC Fund, FSI Growth Fund (specifically dedicated to support research and innovation projects), CDP Equity, "Filiere" Fund, QuattroR.

\section{Empirical analysis}

In this section, we focus on equity investment deals that involved DFIs as acquirors or investors over the past two decades. The issue of participation of DFIs in the market for corporate control is relevant to understand the extent of their countercyclical activity and how they contribute to support economic goals, such as growth, innovation and societal challenges, and as vehicles for state intervention in several sectors. Besides, since detailed 
information on the loans portfolio of banks is not publicly available, we must refer to equity investments to understand which types of economic actors are being mainly benefited by the actions undertaken by the European DFIs in recent years. The existing datasets on mergers and aquisitions (hereafter M\&As) and equity investment deals, and in particular Zephyr (BvD), make it possible to identify and analyze the main acquisitions in which the DFIs or other banks are involved, as well as their main private equity and venture capital investments. Indeed, the analysis on equity investments provides an interesting indication on the main target companies, industries and countries that have benefited by DFIs' financial support. Besides, these types of transactions highlight the contribution made to particularly young companies and particularly innovative sectors, where a direct contribution to risk capital is typically required.

Cefis et al. (2015) finds that M\&As offer to small firms 'the possibility to overcome the innovation threshold: M\&A involvement increases the probability of their making the transition from non-innovator to innovator, in the case of both initial investment in innovative activity or achieving a first sale of an innovative product'. However, this statement specifically refers to acquiring firms that recur to M\&As in order to integrate knowledge and competencies from their targets. An owerview of studies on the impact of M\&As on innovation is presented in Cassiman et al. (2005) and Veugelers (2006), but the potential role of DFIs is not contemplated.

In the next sections, we focus on the main types of equity investment deals where the European DFIs are typically involved: acquisitions, minority stake investments and development capital funding. We analyze the DFIs' targeting strategies (sectors, countries, type of enterprises) and assess whether DFIs acquire (or make minority investments in) targets that are different from enterprises acquired by other financial institutions, both government- or private- owned. We show that the recourse to different deal types typically correspond to different objectives of the investors. Notably, development capital funding is found to be oriented towards the support of young enterprises operative in high-tech and knowledge intensive sectors. Section 4.2 will specifically assess the effectiveness of DFIs' intervention in development capital funding. To this end, we empirically compare the DFIs' probability of successful 'exit' (i.e. exit from investments in the target firms) with that of other banks and financial intermediaries. We find that, other characteristics being equal, the DFIs' investment seem to ensure a higher rate of successful exit. DFIs also participate to acquisition deals whose focus is not innovation, but rather the strategic presence in areas of public interest.

\subsection{Dataset and descriptive statistics}

We extrapolate from the Zephyr data source (produced by BvD) a dataset of deals (M\&As, minority stake investments, private equity and venture capital deals) involving only European financial institutions on the acquirer/investor side to compare the DFIs' deals with an appropriate benchmark.

First of all, based on Zephyr data, we assess the occurrence of DFI-backed deals (i.e. deals with a DFI as acquirer) in the last two decades (1997-2017). We distinguish three main categories of deals:

a) Acquisitions, where the acquirers end up with $50 \%$ or more of the equity of the Target;

b) Minority Stakes, where the stake in the target resulting from the number of shares purchased is relevant but lower than $50 \%$;

c) Development Capital, that is a specific type of minority stake investment, 
typically involving Venture Capitals or Private Equity firms investing in earlystage companies, providing them new financial resources and managerial expertise with the aim to support their growth. The minority stake in the target company usually consists of newly-issued shares.

Development capital funding is the deal type where the incidence of DFIs is the highest (nearly 7 percent, Table 3.4). This points out to the relavant role played by DFIs in supporting innovation, as development capital is typically provided to young firms with a high R\&D profile, as the following analysis of the target's characteristics will clarify.

Table 3.4. M\&As involving financial institutions - Incidence of DFIs (1997-2017)

\begin{tabular}{lccc}
\hline Deal Type & DFI-backed deals & Other deals & DFIs Incidence \\
\hline Acquisitions & 809 & 60,914 & $1.3 \%$ \\
Minority Stake Investments & 446 & 65,212 & $0.7 \%$ \\
Development Capital Funding & 2,378 & 32,129 & $6.9 \%$ \\
\hline TOTAL & 3,633 & 158,255 & $2.3 \%$ \\
\hline
\end{tabular}

Source: Our elaborations on Zephyr

Table 3.5 shows the main sectors targeted by DFIs through development capital deals and M\&As and compares them with the non-DFIs investment strategies. Three main observations emerge:

a) Acquisitions and development capital deals performed by DFIs are directed towards different sectors. In particular, DFIs' equity investments through development capital are mainly addressed to 'high-tech' and 'knowledgeintensive' activities with a clear vocation on R\&D and innovation. By contrast, the focus of DFIs' acquisitions shifts from innovation to the strategic participation in activities of public interest and social utility. Among others, DFIs acquisitions are targeted to firms operating in economic sectors of general interest (ESGI) such as the energy sector, infrastructure capacities, telecommunications networks, transportation services. The different objectives underlying these two types of deal are also confirmed by the different age of target firms that on average is significantly higher in the case of acquisitions than in the case of development capital funding.

b) A closer look at the development capital deals shows that both DFIs and non-DFIs concentrate their investments to innovative sectors. Nevertheless, DFIs' relative weights with respect to non-DFIs' deals reveal a partially different targeting strategy between DFIs and non-DFIs, where non-DFIs concentrate their investments in Computer programming and data processing activities, while DFIs give a relatively higher weight to $\mathrm{R} \& \mathrm{D}$ activities in biotechnology \& natural sciences.

c) When comparing acquisitions, we find that, compared to non-DFIs, DFIs-backed acquisition deals are more oriented towards ESGI. Almost 7\% of DFIs acquisitions are addressed to enterprises operating in ESGI. The percentage drops to $2 \%$ when looking at non-DFIs acquisitions. Other sectors where target industries have the highest relative weight in DFIs' acquisitions with respect to non-DFIs' acquisitions include: Libraries and Other Cultural Activities; Water Treatment and Supply; Manufacture of Food Products. Again, social utility and public interest seem to be the criteria that distinguish the DFIs' targeting strategy in acquisitions with respect 
to their benchamark.

Table 3.5. DFIs' deals: target sectors per type of deal

\begin{tabular}{|c|c|c|c|c|c|}
\hline \multicolumn{3}{|c|}{ Developmental capital } & \multicolumn{3}{|c|}{ Acquisitions } \\
\hline $\begin{array}{l}\text { Main Target Sectors } \\
\text { [NACE code Rev.2] }\end{array}$ & $\begin{array}{l}\text { DFI } \\
(\%)\end{array}$ & $\begin{array}{l}\text { non- } \\
\text { DFI } \\
(\%)\end{array}$ & $\begin{array}{l}\text { Main Target Sectors } \\
\text { [NACE code Rev.2] }\end{array}$ & $\begin{array}{l}\text { DFI } \\
(\%)\end{array}$ & $\begin{array}{l}\text { non- } \\
\text { DFI } \\
(\%)\end{array}$ \\
\hline $\begin{array}{c}\text { Data Processing, Hosting } \\
\text { and Related Activities } \\
{[63.11]}\end{array}$ & 13.48 & 19.51 & ESGI* & 6.65 & 2.16 \\
\hline $\begin{array}{c}\text { Computer Programming } \\
\text { Activities [62.01] }\end{array}$ & 11.05 & 16.14 & $\begin{array}{c}\text { Other Monetary } \\
\text { Intermediation [64.19] }\end{array}$ & 5.82 & 6.20 \\
\hline $\begin{array}{l}\text { Other Research and } \\
\text { Exneriment }\end{array}$ & & & & & \\
\hline $\begin{array}{l}\text { Experimental Development } \\
\text { on Natural Sciences and } \\
\text { Engineering [72.19] }\end{array}$ & 8.75 & 5.76 & $\begin{array}{l}\text { Other Financial Service } \\
\text { Activities [64.99] }\end{array}$ & 2.38 & 4.22 \\
\hline $\begin{array}{c}\text { Research and Experimental } \\
\text { Development on } \\
\text { Biotechnology [72.11] }\end{array}$ & 7.37 & 3.57 & $\begin{array}{l}\text { Engineering Activities } \\
\text { and Related Technical } \\
\text { Consultancy [71.12] }\end{array}$ & 2.14 & 1.09 \\
\hline $\begin{array}{l}\text { Other Software Publishing } \\
\text { [58.29] }\end{array}$ & 6.32 & 7.13 & $\begin{array}{c}\text { Computer } \\
\text { Programming } \\
\text { Activities [62.01] }\end{array}$ & 2.02 & 2.23 \\
\hline
\end{tabular}

Source: Our elaborations on Zephyr

*Note Economic Sectors of general Interest (ESGI) include: Production of Electricity [35.11]; Urban and Suburban Passenger Land Transport [49.31]; Other Passenger Land Transport N.E.C. [49.39];

Construction of Roads and Motorways [42.11]; Wired Telecommunications Activities [61.10]

Further information comes from the comparison of DFI-backed deals and non-DFIs' deals within each category of equity investment. In the case of acquisitions, the highest incidence of DFIs is in Institutional Buy-Out, that is in acquisitions where the main acquirer is a private equity firm. So, an interesting finding is that DFIs often participate to the market for corporate control by leveraging on the expertise of private equity firms (Table 3.6).

Table 3.6. DFIs' incidence in Acquisitions by Deal Type

\begin{tabular}{lccc}
\hline Deal Type & DFI-backed & Other & DFIs Incidence \\
\hline Ordinary Acquisitions & 519 & 43,927 & $1.2 \%$ \\
Institutional Buy-Out & 218 & 9,895 & $2.2 \%$ \\
Management Buy-Out/Buy-In & 72 & 7,092 & $1.0 \%$ \\
\hline TOTAL & 809 & 60,914 & $1.3 \%$ \\
\hline
\end{tabular}

Source: Our elaborations on Zephyr; Note. Ordinary Acquisition: acquisition where a generic acquirer ends up with a $50 \%$ stake or more in the target company. Institutional Buy-Out (IBO): acquisition where a private equity firm ends up with a 50\% stake or more in the target company. Management Buy-Out/Buy-In: acquisition where the existing management or an external team of managers end up with a $50 \%$ stake or more in the target company.

We also assess whether DFIs' targets are mainly domestic or cross-border and, in the 
latter case, if they are located in different countries from targets acquired by benchmarks. Interestingly, we find that the targeting strategy of DFIs in development capital funding contributes to the reallocation of financial resources toward the DFIs' regions (Table 3.7). Indeed, while European financial institutions tend to privilege United Kingdom and the United States, DFIs strongly shift the weight of the targets toward France and Germany and, more in general, towards the countries where the European DFIs are more active in this sense. This seems to confirm the attention paid by the European DFIs to actually sustain innovation in their geographical areas.

Table 3.7. Re-allocation of resources in the DFIs' regions

\begin{tabular}{lcc}
\hline & Non-DFIs-Backed Development Capital & DFIs-Backed Development Capital \\
\hline UK & $23 \%$ & $2 \%$ \\
US & $16 \%$ & $3 \%$ \\
FR & $13 \%$ & $26 \%$ \\
DE & $9 \%$ & $24 \%$ \\
Other & $39 \%$ & $45 \%$ \\
\hline
\end{tabular}

Source: Our elaborations on Zephyr

\subsection{Empirical strategy and discussion of the results}

After having described the DFI's allocation of resources across countries and industries, in this section we assess the effectiveness of the financial support provided by DFIs' development capital funding. In particular, we estimate whether the likelihood of succesfull exit of a target firm is positively associated to the contribution of DFIs' investments in the form of development capital funding. Successful exit means that early investors, including DFIs, are able to sell their equity shares because the target firm goes public with an initial public offering (IPO) or it is acquired by third parties. Indeed, in the literature on venture capital, IPOs and third-party acquisitions are commonly used as a measure of success of the venture capital investments (Brander et al., 2014). Within the whole sample of development capital deals, about 10 percent of the target companies had a successful exit over the studied period. Within this context, we want to test the hypothesis that the DFI funding increases the probability of a successful exit, after controlling for other potential determinants of successful exit.

Accordingly, we estimate a logistic regression where the dependent variable (EXIT) equals 1 when the target enterprise went public or was acquired over the studied period and zero otherwise ${ }^{5}$. The probability of a succesfull exit is explained by an independent dichotomy variable (DFIs-backed dummy), which equals 1 when the single deal (development capital funding) is participated by at least one DFI. Additional explanatory variables include Year, Country and Industry fixed effects to take into account institutional differences, data collection methods, technological differences and also the business cycle and the number of years from the first development capital investment.

The results of the logistic regression model show that the DFIs-backed dummy has a positive and significant coefficient. This confirms that the DFIs' financial support is positively associated with a higher likelihood of successful exit. We check the economic relevance of this result by looking at the Average Marginal Effect, that is the partial effect of a change in the DFIs-backed dummy on the conditional probability of successful exit.

\footnotetext{
${ }^{5}$ Brander et al (2014) introduce a similar approach to assess the impact of government-sponsored venture capitalists on the success of enterprises. Here, instead, we concentrate on DFIs but with a very similar logic.
} 
The estimated marginal effect, obtained using the delta-method, is around 2.5 percentage points and it is statistically significant. This effect can be considered as economically relevant when compared with the unconditional probability of successful exit, which is around 10 percent, as anticipated before (Table 3.8).

Table 3.8. DFI-backed DC funding and EXIT probability

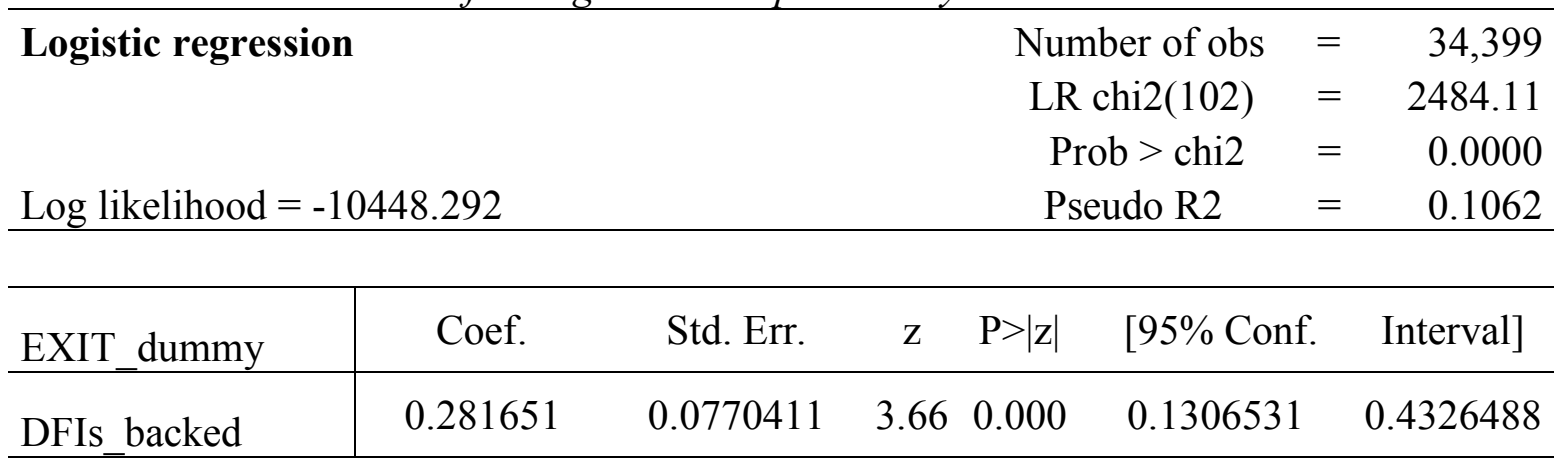

\begin{tabular}{l|cccccc}
\hline Average Marginal Effect (AME) & \multicolumn{7}{c}{ Delta-method } & & & \\
\hline & $\mathrm{dy} / \mathrm{dx}$ & Std. Err. & $\mathrm{z}$ & $\mathrm{P}>|\mathrm{z}|$ & {$[95 \%$ Conf. } & Interval] \\
\hline DFIs_backed & 0.0251016 & 0.0068657 & 3.66 & 0.000 & 0.011645 & 0.0385582 \\
\hline
\end{tabular}

This positive relation between DFIs' support and probability of successful exit should not be necessarily interpreted as a causality relation and it is open to two different interpretations. On the one hand, the over-performance can arise from a selection effect. This would signal that the DFIs are able to select firms that have a higher probability to be successful. On the other hand, over-performance can arise from a treatment effect. This would signal that the DFIs provide effective expertise and other value-added skills and then directly contribute to increase the performance of the target. Further research may help us to distinguish between the two effects. Nonetheless, this first evidence suggests that DFIs development capital funding, on average, is not negatively affected by distortions that may arise, for example, from political objectives. In that case, we would expect the probability of successful exit to be lower than in non-DFIs deals. We consider this finding as very promising for the continuation of research on this topic, also because they empirically support the contemporary debate on the role of DFIs in stimulating innovation and support responses to new global challenges, which goes beyond the fixing of market failures. The next step, in particular, may consist in trying to evaluate the DFIs' contribution to innovation in a more direct way, by recurring to available information on patent production of the target companies.

\section{Concluding remarks}

The wave of privatization that brought at the end of the last century to a step back of the State from the markets has been followed by a countercyclical return of the State in the economy. In a new scenario with global and liberalized markets, traditional direct public intervention in the form of domestic public monopolies has been replaced an indirect intervention vehicolated through new institutions, such as state-invested enterprises 
ultimately controlled by the government by means of minority of stakes, sovereign wealth funds and Development Financial Institutions (DFIs). Notwithstanding some criticisms on their management and the growing space occupied by commercial banks, a large number of DFIs is still in operation in many countries to overcome market failures. Besides, recently, they are increasingly addressing their activity to yield social payoffs and positive externalities for society as a whole, such as stimulating technology innovation and channelling funds to long-term global societal challenges such as climate change. While they have been perceived by public authorities as relevant instruments to promote economic growth, in the academic literature they have been criticized for crowding out the private sector and, thus, limiting rather than supporting the development of private financial institutions. Others argue that DFIs are less effective than their private counterparts in promoting a succesfull exit of the financed enterprises or in supporting innovation. In spite of these opposing visions, most of the researches on DFIs have focused on specific case studies, while a systematic analysis of their goals, contribution to the economic system and performance is still lacking. The present chapter has addressed these issues by focusing on the European DFIs.

To develop a systematic analysis, we have first extracted from Orbis Bank Focus and Orbis databases the European entire population of 132 DFIs. The financial characteristics of DFIs have been described in comparison to European state-owned and private commercial banks. DFIs show a good performance, both in terms of profitability and efficiency, and a lower net interest margin due to a higher value of the cost of servicing liabilities.

Descriptive statistics on our sample also confirm that the SOBs and DFIs played a notable countercyclical role in response to financial crisis. Indeed, since the beginning of the new Millenium, the incidence of DFIs on total assets of the whole European banking system has increased over time due to a greater resilience of their activity compared to private banks in the crisis years. In this period, DFIs have increasingly focused on supporting financially SMEs, digital infrastructure, with a clear focus on technology promotion and innovation. This is confirmed by the information on equity investments involving European financial institutions during the period 1997-2017 which we extrapolated from the Zephyr dataset. We rely on public information on equity investments via M\&As to understand which sectors and firms DFIs are likely to support in comparison to a financial benchmark. Information on acquisitions and minority stakes investments show that in relative terms DFIs' deals are more intensively addressed to the sectors of general interest (energy sector activities, infrastructure capacities, telecommunications networks) compared to the private benchmark. Interestingly, we find that the $7 \%$ of the total "development capital" type of deal have been performed by DFIs. Development Capital are classified as equity investments typically involving Venture Capital or Private Equity institutions which provide financial resources to support early-stage companies. In particular, DFIs have focused their development capital deals in 'high-tech' and 'knowledge-intensive' activities with a higher intensity compared to their private counterparts.

After having described where DFIs tend to address their investment strategies, in the last section of the chapter we have tried to assess the effectiveness of their intervention. Our empirical analysis shows that the DFIs' financial support via development capital funding is positively correlated with the probability successful exit from the target firm. In other terms, on average, firms supported by DFIs are more succesfull in finding new private equity, either by going public with an initial public offering (IPO) or by being acquired 
by third parties. Our analysis cannot clarify whether this over-performance arises from a pre-selection effect - the DFIs are able to select firms with higher probability to be successful - or from a treatment effect - DFIs provide effective expertise and other valueadded skills and then directly contribute to increase the performance of the target. While further research is needed to address this causality issue, these findings allow us to exclude that the increasing presence of DFIs in the market for corporate control does not have any detrimental effect on its functioning. Indeed, we can clearly exclude that DFIs are associated to a lower performance of their targeted firms

The outcomes of our research are novel and can contribute to the debate on the role of DFIs and on their performance. They show that the increasing activity of DFIs is aimed at supporting socially-valuable goals within the market. Their activity in the market for corporate control is not associated with any negative economic implications. If anything, we can exclude the risk that politically-driven financial institutions worsen market efficiency by supporting inefficient firms. Indeed, early-stage enterprises benefeting from the DFIs financial support show a higher than average probability of successful exit. Future research is needed to understand whether and to which extent DFIs effectively support innovative and environmental goals and to understand their heterogeneity with respect to targets, governance, business model, services offered, size and location.

\section{References}

Akerlof, G. (1970). The market for lemons: quality uncertainty and the market mechanism. Quarterly Journal of Economics, 84, 488-500.

Alperovych, Y., Hübner, G., 2015. How does governmental versus private venture capital backing affect a firm's efficiency? Evidence from Belgium. Journal of Business Venturing, Volume 30, Issue 4, 508-525

Armenda ÅLriz de Aghion, B. 1999. Development banking. Journal of Development Economics, 58, 83-100.

Bacchiocchi, E., Ferraris, M., Florio, M., Vandone, D., 2017. State-owned banks in the market for corporate control. Journal of Economic Policy Reform, 1-28.

Bleda M., Del Rio P. (2013). The market failure and the sistemi failure ratoinales in technological innovation systems. Research policy, 42: 1039-1052

Bortolotti, B. and Faccio, M. 2009. Government control of privatized firms. Review of Financial Studies 22(8): 2907-2939.

Brander, J. A., Du, Q., \& Hellmann, T. (2014). The effects of government-sponsored venture capital: International evidence. Review of Finance. 19: pp. 571-618

Bremmer, I. (2009). State Capitalism Comes of Age-The End of the Free Market. Foreign Aff., 88, 40.

Cassiman, Bruno, Massimo Colombo, Paola Garrone, and Reinhilde Veugelers. 2005. The impact of M\&A on the R\&D process: an empirical analysis of the role of technological- and market-relatedness. Research Policy 34 (2), 195-220.

Cefis, Elena, and Orietta Marsili. 2015. Crossing the Innovation Threshold through Mergers and Acquisitions. Research Policy. 44, 3, 698-710.

Christiansen, H. and Kim, Y. (2014), "State-Invested Enterprises in the Global Marketplace: Implications for a Level Playing Field", OECD Corporate Governance Working Papers, No. 14, OECD Publishing. 
Clifton J., Díaz-Fuentes, D., Revuelta, J. 2014. Financing utilities: How the role of the European Investment Bank shifted from regional development to making markets. Utilities Policy. Vol 29, pp.63-71.

Clifton, J., Díaz-Fuentes, D., and Gómez, A. L. (2018) The European Investment Bank: Development, Integration, Investment?. JCMS: Journal of Common Market Studies, 56: 733-750. doi: 10.1111/jcms.12614.

Coase, R. (1960). The problem of social cost. Journal of Law and Economics, 3, 1-44.

De la Torre A., Ize A. 2009. Regulatory reform: integrating paradigms. The World Bank.

De Olloqui F. 2013. Public Development Banks: Toward a New Paradigm?. Report, Inter-American Development Bank, Washington, DC.

Diamond W. 1957. Development Banks. The Economic Development Institute, The Johns Hopling Press

Dinç, I.S., 2005. Politicians and banks: Political influences on government-owned banks in emerging markets. Journal of Financial Economics 77(2), 453-479.

Eslava M., Freixas W. 2016. Public Development Banks and credit market imperfections. Documentos CIDE n.6

European Commission, 2014. An Investment Plan for Europe. Communication from the Commission to the European Parliament, the Council, the European Central Bank, the European Economic and Social Committee, the Committee of the Regions and the European Investment Bank. COM(2014)903 final, Brussels.

European Investment Bank 2014. Financial Statement

Foray D., Mowery D.C., Nelson R.R. (2012). Public R\&D and societal challenges: what lessons from mission R\&D programs? Research Policy, 41: 1697-1702

Francisco, M., Mascaró, Y., Mendoza, J. C., and Yaron, J. (2008). Measuring the performance and achievement of social objectives of development finance institutions. Policy Research Working Papers. Washington, DC: World Bank.

Greenwald, B., \& Stiglitz, J. (1986). Externalities in economies with imperfect information and incomplete markets. Quarterly Journal of Economics, 101, 229-264.

Gutierrez, E., Rudolph, H., Homa, T., and Beneit, E.B. (2011). Development banks: role and mechanisms to increase their efficiency. Policy Research working paper ; no. WPS 5729. Washington, DC: World Bank.

Hardie, I. and Howarth, D. (eds) (2013). Market-based banking and the International financial crisis. Oxford, Oxford University Press

Hicks, J.R. (1935). Annual survey of economic theory: the theory of monopoly. Econometrica: Journal of the Econometric Society, 1-20

Lazzarini, S., Musacchio, A., Bandeira-de-Mello, R., and Marcon, R. (2015). What Do Development Banks Do? Evidence from Brazil, 2002-2009, World Development, 237253

Leibenstein (1966). Allocative efficiency vs X-efficiency. The American Economic Review 56.3 (1966), 392-415.

de Luna-Martinez, J., Vicente, C.L. (2012). Global survey of development banks. Policy Research Working Paper, 5969. Washington, DC: World Bank.

Mazzucato, M., and Penna, C.C.R. 2016. Beyond Market Failures. The Market Creating and Shaping Roles of State Investment Banks. Journal of Economic Policy Reform 19(4): 305-326.

Mertens, D., and Thiemann, M. (2019). Building a hidden investment state? The European Investment Bank, national development banks and European economic 
governance, Journal of European Public Policy, 26:1, 23-43, DOI: 10.1080/13501763. 2017.1382556

Micco, A., Panizza, U., and Yanez, M. (2007). "Bank ownership and performance. Does politics matter?" Journal of Banking \& Finance, 31(1): 219-241.

Musacchio A., Lazzarini S.B. 2014. Reinventing State Capitalism. Leviathan in Business, Brazil and Beyond. Harvard University Press, Cambridge, MA: Harvard University Press.

Musacchio, Aldo; Sergio G. Lazzarini; Pedro Makhoul; Emily Simmons (2017) "The Role and Impact of Development Banks." World Bank Working Paper, 2017.

OECD. 2012. Global Survey of Development Banks. Policy Research Working Paper 5969, February.

Orhangazi O. (2008). Financialization and capital accumulation in the non-financial corporate sector: a theoretical and empirical investigation on the US economy: 19732003. Cambridge Journal of Economics, 32, 863-886.

Robinson, N. (2009), The European Investment Bank: The EU's Neglected Institution. JCMS: Journal of Common Market Studies, 47: 651-673. doi: 10.1111/ j.1468-5965.2009.01818.x

Sapienza, P., 2004. The effects of government ownership on bank lending, Journal of Financial Economics 72(2), 357-384.

Schmit, M., Denuit, T., Gheeraert, L., Warny, C., 2011. Roles, Missions and Business Models of Public Financial Institutions in Europe (No. 2011/5). SUERF Studies. SUERF - The European Money and Finance Forum

Sorsa M. and Van Der Zwan N. (2016). Losing patience: business, labor and pension fund capitalism in the United States, Finland and the Netherlands. Socio-economic review.

Tuijnman A. 2009. The education lending policy of the European Investment Bank. European Journal of Education, 44(1), 111-125.

Veugelers, Reinhilde. 2006. Literature review on M\&A and R\&D. In: Cassiman, B., Colombo, M.G. (Eds.), Mergers and Acquisitions-The Innovation Impact. Edward Elgar Publishing, Northampton, MA.

Yeyati, E.L., Micco, A., Panizza, U., 2004. Should the government be in the banking business? The role of state-owned and development banks. Research Working Paper 517 , Washington: Inter-American Development Bank.

Yeyati E. L., Micco A., Panizza U 2007. A rappraisal of State-Owned Banks. Economica 7(3): 209-247.

World Bank. 2013. Global Financial Development Report 2013: Rethinking the Role of the State in Finance. Washington, DC: World Bank.

World Bank. 2011. Development Banks: Role and Mechanisms to Increase their Efficiency. Policy Research Working Paper 5729. 